\title{
Nucleic acids in inclusion bodies obtained from $E$. coli cells expressing human interferon-gamma
}

\author{
Elena Krachmarova(D, Ivan Ivanov and Genoveva Nacheva*
}

\begin{abstract}
Background: Inclusion bodies (IBs) are protein aggregates in recombinant bacterial cells containing mainly the target recombinant protein. Although it has been shown that IBs contain functional proteins along with protein aggregates, their direct application as pharmaceuticals is hindered by their heterogeneity and hazardous contaminants with bacterial origin. Therefore, together with the production of soluble species, IBs remain the main source for manufacture of recombinant proteins with medical application. The quality and composition of the IBs affect the refolding yield and further purification of the recombinant protein. The knowledge whether nucleic acids are genuine components or concomitant impurities of the IBs is a prerequisite for the understanding of the IBs formation and for development of optimized protocols for recombinant protein refolding and purification. IBs isolated from Escherichia coli overexpressing human interferon-gamma ( $\mathrm{hIFN}$ ), a protein with therapeutic application, were used as a model.

Results: IBs were isolated from E. coli LE392 cells transformed with a hIFNy expressing plasmid under standard conditions and further purified by centrifugation on a sucrose cushion, followed by several steps of sonication and washings with non-denaturing concentrations of urea. The efficiency of the purification was estimated by SDS-PAGE gel electrophoresis and parallel microbiological testing for the presence of residual intact bacteria. Phenol/chloroform extraction showed that the highly purified IBs contain both DNA and RNA. The latter were studied by UV spectroscopy and agarose gel electrophoresis combined with enzymatic treatment and hybridization. DNA was observed as a diffuse fraction mainly in the range of 250 to $1000 \mathrm{bp}$. RNA isolated by TRIzol ${ }^{\circledR}$ also demonstrated a substantial molecular heterogeneity. Hybridization with ${ }^{32}$ P-labelled oligonucleotides showed that the IBs contain rRNA and are enriched of hIFNy mRNA.
\end{abstract}

Conclusions: The results presented in this study indicate that the nucleic acids might be intrinsic components rather than co-precipitated impurities in the IBs. We assume that the nucleic acids are active participants in the aggregation of recombinant proteins and formation of the IBs that originate from the transcription and translation machinery of the microbial cell factory. Further studies are needed to ascertain this notion.

Keywords: Inclusion bodies, Nucleic acids, E. coli, Recombinant protein production, Human interferon-gamma, Protein aggregation

*Correspondence: genoveva@bio21.bas.bg; genoveva_nacheva@hotmail. com

Institute of Molecular Biology "Roumen Tsanev", Bulgarian Academy of Sciences, Academic Georgi Bonchev Str., Blok 21, 1113 Sofia, Bulgaria

\section{Introduction}

Escherichia coli is one of the most preferable microbial factory for production of recombinant proteins for research, diagnostics and medical use because of its easy, fast and cheap cultivation, well investigated genetics and physiology as well as for the availability of 
numerous tools for genetic manipulation [ 1 and references therein]. It is well known that the overexpression of eukaryotic proteins in E. coli often causes formation of inclusion bodies (IBs) [2], containing mainly improperly folded proteins [3]. For a long time, it has been believed that the aggregated proteins are immunogenic and partly or completely devoid of biological activity [4]. At present, increasing evidence show that IBs have amyloidlike structure and comprise aggregated as well as native folded proteins with preserved biological activity [2]. This fact, together with the mechanical stability and high porosity of the IBs has defined them as unconventional functional materials with a wide spectrum of applications in biotechnology and biomedicine [5-7]. Recently, first report towards in vitro preparation of tailored and chemically defined IBs with potential for clinical application was published [8]. In spite of these first steps, the largescale clinical application of IBs is still hindered by their undefined heterogeneous composition and the presence of hazardous contaminants from the bacterial cell, especially endotoxins [9]. Thus IBs remain a main source for production of pure biologically active recombinant proteins for medical purposes that can be isolated upon cell disruption, solubilisation, subsequent refolding and purification [10]. Furthermore, to turn IBs aggregation into greatest use, new combinatorial approaches at each step was proposed [11].

Protein folding and IBs formation is extensively discussed in a number of reviews [1, 12-15]. For a long time, protein aggregation has been considered as a process driven by hydrophobic interactions between fully-denatured protein molecules, however, increasing evidence indicate that protein aggregates are composed of partially unfolded or misfolded proteins linked by unspecific hydrophobic interactions [14, 16, 17]. Therefore, aggregation seems to be a competitive reaction to folding, depending on specific folding behaviour and conditions [18]. It is influenced by various factors such as protein size, presence of specific hydrophobic compartments in the molecule, pI, protein abundance [19, 20], high local concentration of the polypeptide chains emerging from ribosomes [21], limited amount of bacterial chaperones and proteases, which affect either folding or degradation of the unfolded or misfolded polypeptides [22, 23].

The chemical composition of IBs still remains obscure. It varies in a broad range and depends on the properties of the specific recombinant protein, fermentation conditions, host genetic background, IBs purification procedures, etc. [18]. Apparently, the major component of the bacterial IBs is the target recombinant protein [24-27]. In addition, they can also contain various contaminants such as lipids, nucleic acids, endogenous cell proteins, chaperones, etc. [28]. Since chaperons assist in protein folding, they are the main cell components "controlling" protein aggregation [29]. Among them, the heat shock proteins IbpA and IbpB [30-32] and DnaK and GroEL $[32,33]$ have been found in bacterial IBs. There is evidence that the IBs contain also plasmid DNA [34], ribosomal RNA, RNA polymerase subunits [35, 36], ribosomal proteins L13 [36], L7 and L12 [24], elongation factor Tu [37], membrane proteins OmpF, OmpC, and OmpA [24], membrane phospholipids and cellular RNAs [38]. Based on these findings some authors assume that the protein aggregation in vivo occurs simultaneously with the protein synthesis $[35,36]$. Taking into account that in most of these studies the IBs have not been precisely purified, Rinas and Bailey [24] suggest that the cellular ingredients found in IBs co-precipitate during their isolation.

The quality and composition of the IBs affect the refolding yield and further purification of the recombinant protein. It has been shown that fully denatured mammalian proteins show unusually high solubility in nucleic acid-free pure water [39]. Since the recombinant proteins that are produced as pharmaceuticals are mainly mammalian proteins, the presence of nucleic acids in their preparation is critical for their refolding because the nucleic acids actively participate in the protein aggregation process via direct electrostatic interactions with partially folded or unfolded proteins. The literature survey shows that most of the studies on E. coli IBs carried so far are focused on protein composition and mechanisms of aggregation, whereas the data concerning nucleic acids are scarce and vague. Bearing in mind that the recombinant proteins manufactured for medical applications should be free of nucleic acids, we have focussed in this study on the content and nature of nucleic acids in highly purified E. coli IBs. As a model in this study we use IBs isolated from E. coli LE392 overexpressing human interferon-gamma (hIFN $\gamma$ ).

\section{Results \\ Purification of hIFNY IBs}

To study the type of nucleic acids co-aggregating with recombinant hIFNY in E. coli cells we developed a three step procedure for purification of IBs from intact bacterial cells and subcellular components (Fig. 1). The first step included additional sonication of the crude IBs pellet followed by treatment with $100 \mu \mathrm{g} /$ $\mathrm{ml}$ lysozyme. According to literature data, the combination of these two procedures should lead to IBs free from intact bacterial cells [40]. We observed, however, that substantial amount of viable $E$. coli cells still remained in the pellet (Fig. 1). The latter were successfully removed by centrifugation on a cushion of $20 \%$ sucrose that comprised the second step of the purification procedure. Further the IBs were collected by 
Standard procedure for IBs isolation
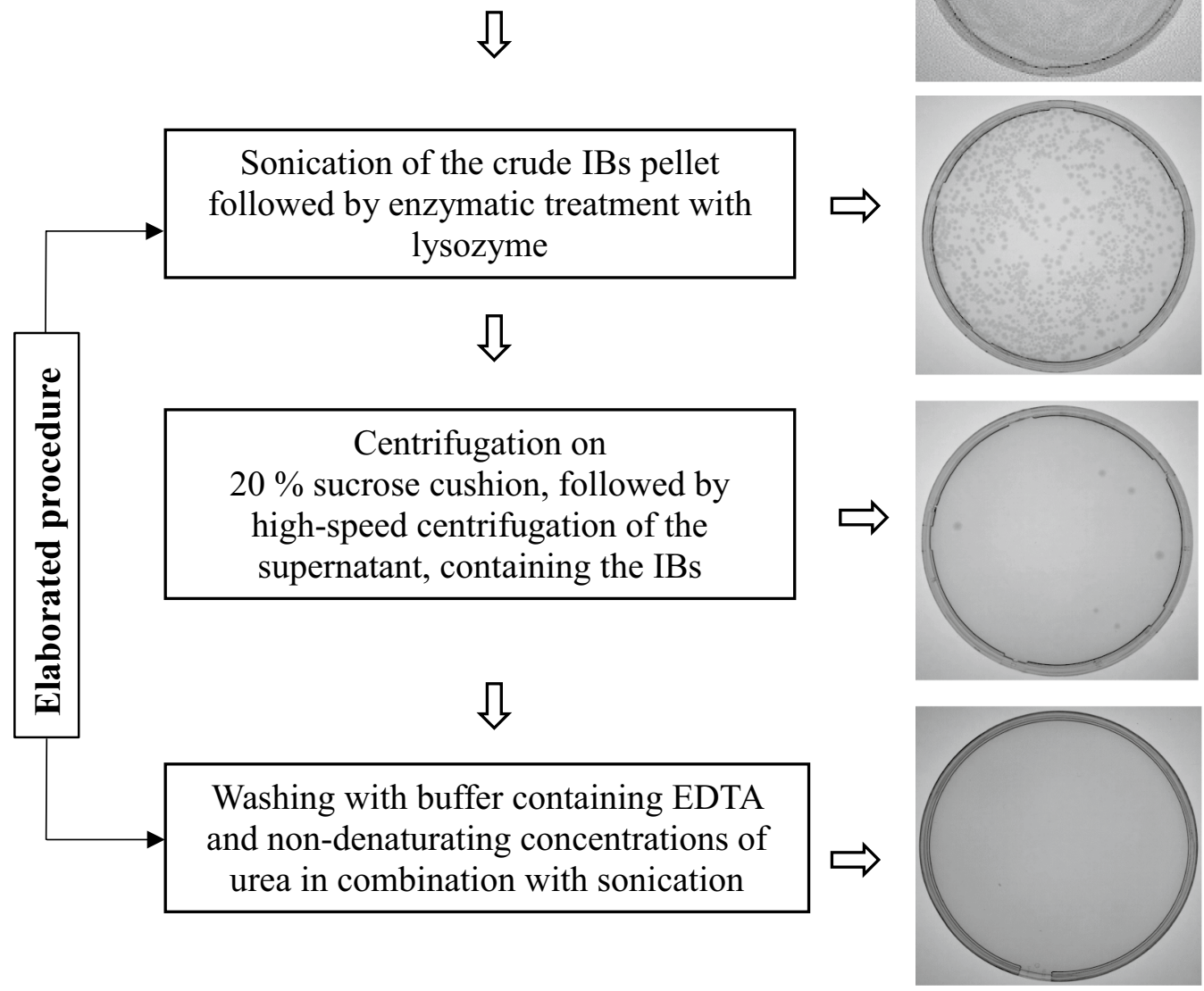

$\sqrt{ }$

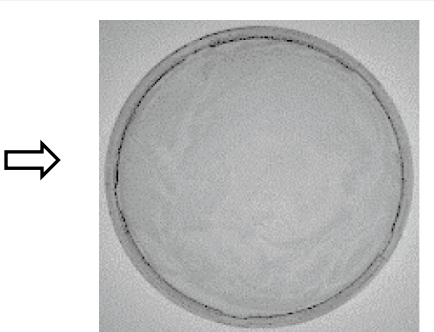

Fig. 1 Schematic illustration showing the IBs purification steps and analysis for presence of viable bacterial cells

centrifugation of the supernatant at $13,000 \mathrm{rpm}$ for $20 \mathrm{~min}$ at $4{ }^{\circ} \mathrm{C}$. The pellet thus obtained contained negligible amount (sporadic) of bacterial cells (Fig. 1). During the third purification step the IBs were washed twice with washing buffer containing EDTA and nondenaturing concentrations of urea $(1 \mathrm{M})$. Between the washing steps the IBs were sonicated and collected by centrifugation. This procedure proved to be essential for the quality and yield of the purified IBs since no bacterial growth was further observed (Fig. 1).

The IBs electrophoretic pattern was also used as a criterion for their purity. Figure 2 illustrates the significant difference in the protein composition of the IBs prepared by the standard procedure [41] and after the additional purification.

\section{Characteristics of nucleic acid in purified hIFN $\mathrm{Y}$ IBs}

Nucleic acids were isolated from purified IBs by phenolchloroform extraction and precipitation with ethanol. Their concentration and UV spectra were analysed by NanoDrop ${ }^{\circledR}$. The UV spectra showed absorption maxima at $260 \mathrm{~nm}$ and typical for the nucleic acids $\mathrm{A}_{260 / 280}$ and $\mathrm{A}_{260 / 230}$ ratios (Additional file 1: Fig. S1). The agarose electrophoretic pattern of the isolated total nucleic acids (Fig. 2a) revealed two main fractions-a high-molecular weight fraction (above 10,000 bp) and a more diffusive one in the range of 250 to $1000 \mathrm{bp}$.

One can speculate that the low mobility fraction (conditionally called high-molecular, Fig. 3a) consists of genomic or multimeric plasmid DNA, or a mixture of both. In order to investigate the origin of this fraction, 


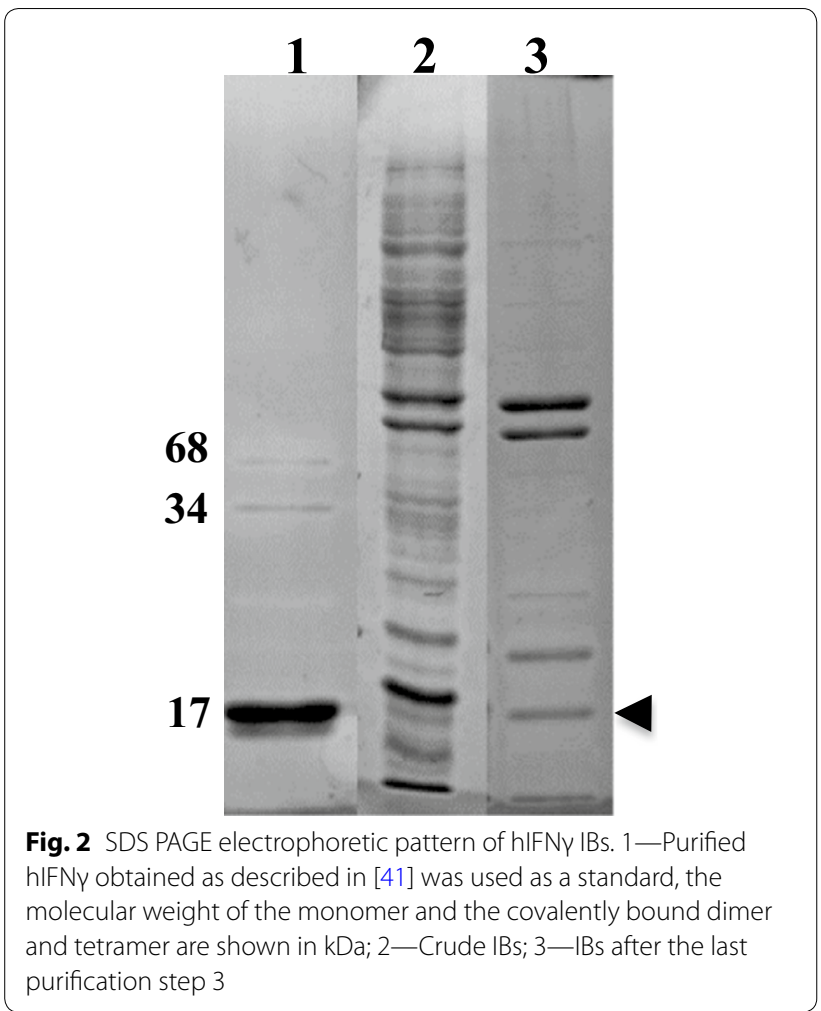

samples were treated with the restriction endonucleases XhoI and HindIII. They were chosen because of the fact that the $E$. coli genome has multiple restriction sites for both enzymes, while no Xhol site exists in the expression plasmid pP1SD-hIFN $\gamma$. Therefore, any change in the mobility of the high-molecular fraction upon treatment with XhoI would mean that it consists of genomic DNA. Since the expression plasmid bears a unique HindIII site, the treatment with this enzyme would generate a distinguished single fraction from eventual plasmid concatemers.

As seen from Fig. 3b, c, the digestion with neither of the enzymes resulted in any significant change in the mobility of the high-molecular fraction. Its resistance to both restriction endonucleases suggested that this fraction might be composed of RNA rather than DNA. In order to check this assumption, samples were further treated with DNase I and a mixture of RNase A and RNase T1. In addition, to test for the presence of residual proteins that could form stable complexes with the nucleic acids, the sample was also treated with Proteinase $\mathrm{K}$.

Figure $3 \mathrm{~d}$ shows that the mixture of RNase $\mathrm{A}$ and RNase $T_{1}$ resulted in a complete hydrolysis of the highmolecular fraction thus confirming that it consists of RNA fragments that under non-denatured electrophoresis conditions have preserved higher order structures and migrate slow. Surprisingly, DNase I degraded entirely the high mobility fraction (250-1000 bp). This means that it is composed of very heterogeneous in size DNA fragments. Proteinase $\mathrm{K}$ did not cause changes in the mobility of any electrophoretic fraction thus

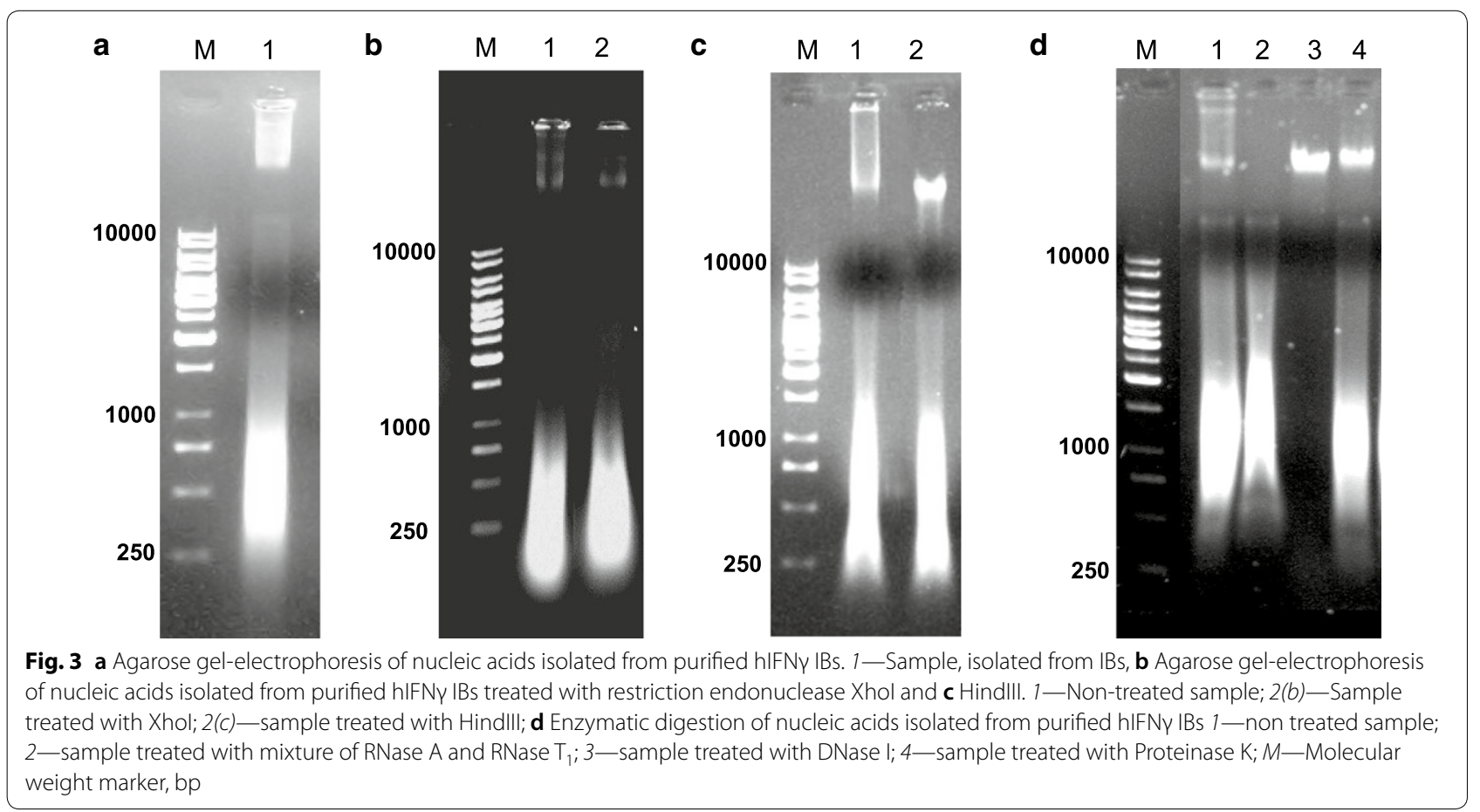


proving that the nucleic acids isolated from IBs were devoid of interfering proteins.

\section{Characterization of RNA isolated from purified hIFN $\gamma$ IBs}

To characterize the RNA in highly purified IBs, RNA was isolated using TRIzol $^{\circledR}$ under conditions recommended by the producer [42]. The obtained UV spectrum was typical for RNA and showed absorption maxima at $260 \mathrm{~nm}$ (Additional file 1: Fig. S2). The amount of the total RNA related to that of the IBs showed that its average content was $0.2 \mathrm{mg}$ per $1 \mathrm{~g}$ wet purified IBs. The electrophoretic pattern of the obtained sample (Fig. 4a) showed that it consists of three main fractions-a slow-mobility one (high molecular mass), similar to the one isolated by the phenol-chloroform extraction (Fig. 3a) and two others corresponding to the bacterial $23 \mathrm{~S}$ and $16 \mathrm{~S}$ rRNA. The latter means that whole ribosomes have been entrapped at the time of recombinant hIFN $\gamma$ aggregation and IBs formation.

To shed light on the origin of the RNA isolated from IBs, hybridization was carried out with two radiolabelled oligonucleotides of which one was complementary to the $5^{\prime}$ end of the hIFNY mRNA and the second was complementary to the E. coli $16 \mathrm{~S}$ rRNA. As shown in Fig. 4b, c, both oligonucleotides demonstrated specific hybridization with the RNA sample isolated from purified IBs. The hybridization signal in the DNasetreated sample (Fig. 4b, A3) proved that hIFNY mRNA, but not plasmid DNA encoding the hIFNY gene was present in the samples.

\section{Discussion}

Inclusion bodies formation in bacterial cells overexpressing eukaryotic proteins is a well-known phenomenon. Although the IBs are routinely used for isolation of recombinant proteins, systematic studies on their chemical composition and mechanism of their formation are sporadic and rare. There is no consensus on whether the IBs formation is a specific process affecting the recombinant protein only or it happens with the participation of other cellular components. Hartley and Kane [35] have identified ribosomal RNA, RNA polymerase subunits and various forms of plasmid DNA in bovine somatotropin IBs. Since the latter have been non-purified, it is not clear whether the observed substances are genuine components of the IBs or co-precipitated cellular impurities. Rinas and Bailey [24] found ribosomal proteins L7/ L12 in TEM $\beta$-lactamase and $\beta$-galactosidase IBs, considering them as co-precipitated protein contaminants. In NMR studies Wasmer and co-workers [38] found RNA in HET-s(218-289) IBs washed 3 times with pure water that has not been further observed after additional purification. Other authors have detected nucleic acids in IBs, but they have regarded them as non-specific impurities rather than as their genuine components [24, 26]. Chaturvedi and co-workers [34] observed that the $\delta$-endotoxin CryIAc exists in E. coli IBs in the form of tight complexes with chromosomal and plasmid DNA. However, this might be due to the presence of a large hydrophobic domain in the molecule of the recombinant $\delta$-endotoxin or to a poor purification of the IBs.

To minimize the impurities in IBs, we developed an elaborated procedure for purification of hIFNY IBs by
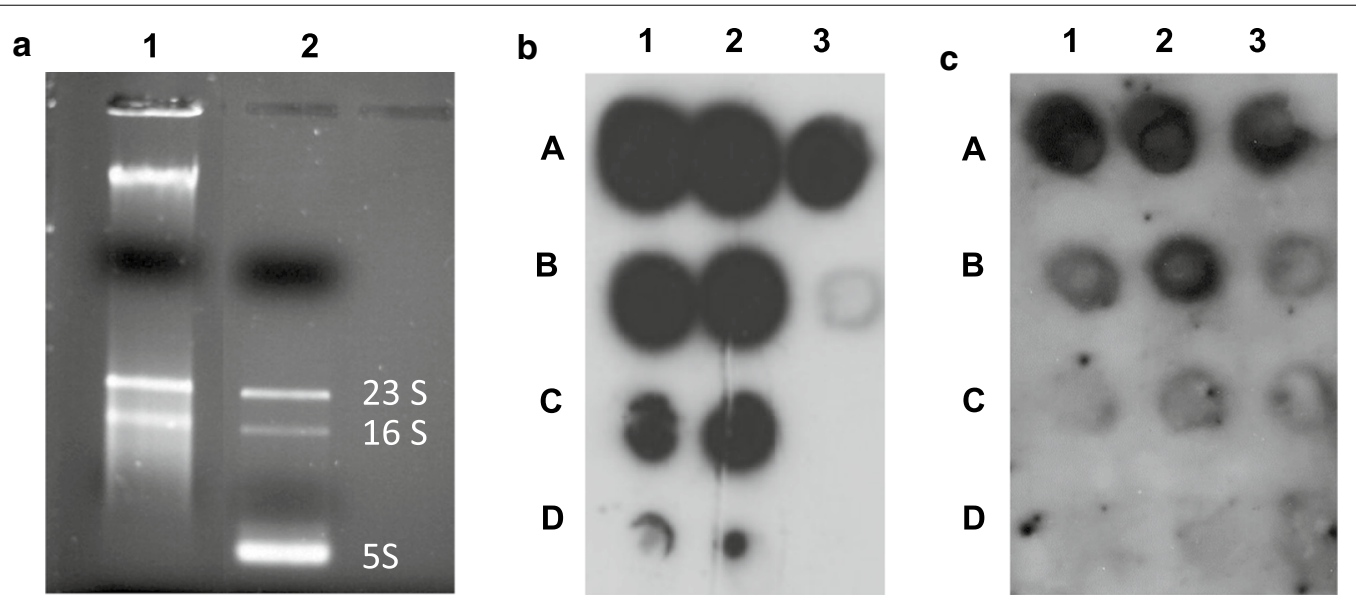

Fig. 4 a Agarose gel-electrophoresis of RNA, isolated from purified hIFNy IBs. 1—RNA, isolated from purified hIFNy IBs; 2 -total RNA, isolated from non-transformed E. coli cells. b, c Dot-blot hybridization of RNA isolated from hIFNY IBs. b RNA was dotted on nitrocellulose filters, hybridized with ${ }^{32}$ P-labelled oligonucleotide specific for hIFNy mRNA, striped and $\mathbf{c}$ reprobed with oligonucleotide specific for the E. coli $165 \mathrm{rRNA}$. Total amount of RNA on the dots: $A 1$ and $A 2-10 \mu \mathrm{g} ; B 1$ and $B 2-5 \mu \mathrm{g} ; C 1$ and $C 2-2.5 \mu \mathrm{g} ; D 1$ and $D 2-1 \mu \mathrm{g} ; A 3-10 \mu \mathrm{g}$ RNA pre-treated with DNase; $B 3-10 \mu \mathrm{g}$ total RNA isolated from transformed E. coli cells; $C 3$ and $D 3-10 \mu \mathrm{g}$ total RNA isolated from non-transformed E. coli cells 
introducing a centrifugation step on sucrose cushion followed by twofold ultrasonication and extensive washing between the latter steps with non-denaturing concentrations of urea. Literature data show that sonication of IBs destroys the non-covalent interactions between proteins and nucleic acids thus helping their separation by centrifugation [43]. Based on this study we believe that the extensive ultrasonication followed by washing is critical for the efficient removal of co-precipitated nucleic acids from the IBs. The bacterial growth test (see Fig. 1) shows that these additional steps improve also the disintegration of the residual bacterial cells in the IBs fraction. Our results are supported also by the results of Futami and co-authors [44] who extracted equal amounts of nucleic acids from extensively sonicated IBs and IBs treated with a mixture of DNase and RNase. Thus we assume that the nucleic acids found in highly purified hIFNY IBs are their genuine components.

As mentioned above, exploring several recombinant proteins Futami and co-authors [44] have obtained DNA and RNA from IBs treated with nucleases and concluded that the inclusion bodies contain nucleic acids that are tightly bound to the expressed unfolded protein. They have suggested that the most important factor causing aggregates during the folding is the electrostatic interaction between unfolded protein and anionic contaminants such as nucleic acids. Our results support this conclusion. Furthermore, we characterized the nature of the RNA obtained from hIFNY IBs as hIFNY mRNA and $E$. coli ribosomal RNA. We explain this by the fact that the processes of replication, transcription and translation are not space and time segregated in bacteria, which allows immediate interactions between the expression plasmid DNA, mRNA, translating ribosomes and newly synthesized polypeptide chains (both completely and partially folded). This is particularly valid for the expression of genes under strong constitutive promoters and strong SD sequences, as is the case with the expression plasmid pP1SD-hIFNy used in this study. Our assumption is supported by the fact that the initiation of the chromosomal DNA replication in E. coli is dependent on its transcriptional activity [45] where a direct interaction between DnaA (a bacterial replication initiator protein) and RNA polymerase has been found. In addition, we have previously shown that the segregation of the expression plasmid pP1SD-hIFNY strongly depends on the level of hFN $\gamma$-mRNA in E. coli cells [46, 47].

Probably many factors, such as amino acid composition, solubility, affinity to the cell membrane and other properties of the recombinant protein might affect the formation of inclusion bodies and the captivation of nucleic acids and even whole ribosomes. We speculate however, that the natural platform for this phenomenon is the lack of compartmentalization in bacteria due to which the genetic processes occur in one "test tube" contributing to the electrostatic interaction between unfolded protein and nucleic acids. Therefore, we assume that nucleic acids might be components of IBs formed by different target proteins. The aggregation of proteins (including recombinant hIFNY) in E. coli cells and therefore the IBs formation could be further enhanced by the non-enzymatic glycosylation (glycation) that occurs in vivo [48-50]. The advanced glycation end products (AGEs) promote protein-protein and protein-nucleic acids cross-linking [51] that might contribute to an even more complex structure of the E. coli IBs.

\section{Conclusions}

Based on the results presented in this study we conclude that the highly purified IBs isolated from E. coli cells overexpressing recombinant hIFN $\gamma$, contain tightly bound nucleic acids, which might be regarded as an integral part of their structure. They cannot be removed by extensive sonication and washing with non-denaturing urea solutions. They represent both sheared DNA and RNA that is composed of ribosomal and target protein mRNA. Although the role of nucleic acids in the formation of IBs remains to be clarified, we suppose that they come from gene expressing complexes (expression plasmid, mRNA and translating ribosomes) and actively participate in the aggregation process by electrostatic interactions with unfolded or partially folded proteins. Further experiments are needed to show whether these finding are valid for other recombinant proteins aggregating in IBs. Besides its fundamental significance, this finding is important for the biotechnological practice. It could serve as basis for development of new technologies for manufacturing of recombinant proteins based on preliminary removal or suppression of the co-aggregation of nucleic acids in IBs. The proteins thus obtain is expected to have improved purity and stability in water solutions.

\section{Methods \\ Isolation of crude hIFN $\gamma$ IBs fraction}

Escherichia coli LE391 cells were transformed with a plasmid for constitutive expression of hIFNy. The cells were grown and lysed in $200 \mathrm{ml}$ of $1 \mathrm{M}$ urea, $0.4 \mathrm{M}$ guanidinium hydrochloride, $20 \mathrm{mM}$ Tris- $\mathrm{HCl}, \mathrm{pH} 8.8$ by ultrasonic disintegration as described by Petrov et al. [41]. The pellet was collected by centrifugation at $14,000 \mathrm{rpm}$ for $30 \mathrm{~min}$ and stored at $4{ }^{\circ} \mathrm{C}$.

\section{Purification of hIFNY IBs}

The crude pellet of hIFNY IBs was suspended in TE buffer $\mathrm{pH}$ 7.4, sonicated (3 cycles of $1 \mathrm{~min}$ at amplitude $50 \%)$ and $100 \mu \mathrm{g} / \mathrm{ml}$ lysozyme was added at a $1 / 10 \mathrm{v} / \mathrm{v}$ 
ratio. The suspension was incubated at $37{ }^{\circ} \mathrm{C}$ for $1 \mathrm{~h}$, overlaid on a $20 \%$ sucrose cushion at $1 / 3 \mathrm{v} / \mathrm{v}$ ratio and centrifuged at $4{ }^{\circ} \mathrm{C}$ for $20 \mathrm{~min}$ at $5000 \mathrm{rpm}$. The cell pellet was removed and the supernatant above the sucrose layer was collected and centrifuged at $4{ }^{\circ} \mathrm{C}$ for $15 \mathrm{~min}$ at $13,000 \mathrm{rpm}$. The pellet was suspended in washing buffer (0.02 M Tris, $\mathrm{pH} 8,8 ; 1 \mathrm{M}$ urea and $0.01 \mathrm{M}$ EDTA) at 1/10 $\mathrm{v} / \mathrm{v}$ ratio, homogenized on a vortex mixer and centrifuged at $4{ }^{\circ} \mathrm{C}$ for $15 \mathrm{~min}$ at $14,000 \mathrm{rpm}$. After centrifugation, the supernatant was discarded and the pellet was re-suspended again in washing buffer. After sonication (3 cycles of $1 \mathrm{~min}$ at amplitude 50\%) and centrifugation under the same conditions, the pellet was suspended in $1 / 10 \mathrm{v} / \mathrm{v}$ washing buffer.

\section{Analysis of the IBs for presence of viable bacterial cells}

The presence of viable bacterial cells was monitored by seeding on a solid LB agar (1.7\%), supplemented with tetracycline $(12.5 \mathrm{mg} / \mathrm{ml})$ and ampicillin $(100 \mathrm{mg} / \mathrm{ml})$, at each purification step.

\section{Analysis of the IBs protein composition}

The protein pattern of the IBs fraction was monitored by Laemmli SDS-polyacrylamide gel electrophoresis. Prior loading on the $15 \%$ SDS-polyacrylamide gel, the IBs sample was resuspended in loading buffer $(4 \times$ buffer: $400 \mathrm{mg}$ SDS, $5 \mathrm{ml} 0.5 \mathrm{M}$ Tris $\mathrm{pH}, 6.8,5 \mathrm{ml} 100 \%$ glycerol, bromophenol blue), incubated for $5 \mathrm{~min}$ at $95{ }^{\circ} \mathrm{C}$, and centrifuged for $5 \mathrm{~min}$ at 12,000 rpm.

\section{Isolation of nucleic acids from IBs}

Purified IBs were suspended in $10 \mathrm{v} / \mathrm{v}$ washing buffer, incubated at $37^{\circ} \mathrm{C}$ for $15 \mathrm{~min}$ followed by $5 \mathrm{~min}$ at $60^{\circ} \mathrm{C}$ and cooled on ice. The isolation of nucleic acids with phenol-chloroform was carried out according to Sambrook and Russell [52]. The obtained nucleic acids were precipitated by $1 / 3 \mathrm{v} / \mathrm{v}$ ethanol at $-20^{\circ} \mathrm{C}$ [53]. The pellet was collected by centrifugation and dissolved in $50 \mu \mathrm{l}$ TEbuffer (pH 7.4). Nucleic acids concentration was measured by Nanodrop ${ }^{\circledR}$ ND-1000 (NanoDrop Technologies, Inc., USA) at $\lambda=260 \mathrm{~nm}$ and the electrophoretic pattern was determined by standard agarose gel electrophoresis.

\section{Enzymatic treatment of nucleic acids isolated from IBs}

Nucleic acids extracted from purified IBs were treated with RNAse A (Thermo Scientific ${ }^{\mathrm{TM}}, 10 \mathrm{mg} / \mathrm{ml}$ ), RNase T1 (Thermo Scientific ${ }^{\mathrm{TM}}, 1000 \mathrm{U} / \mathrm{ml}$ ), DNAse I, restriction endonucleases XhoI and HindIII (New England BioLabs) and Proteinase $\mathrm{K}$ (Roche, $10 \mu \mathrm{g} / \mathrm{ml}$ ) following the manufacturers' protocols.

\section{Isolation of RNA from hIFN $\mathrm{IBs}$}

RNA was extracted from purified IBs by TRIzol ${ }^{\circledR}$ reagent $\left(\right.$ Invitrogen $^{\mathrm{TM}}$ ) following the manufacturer's protocol. After the last step, RNA was dissolved in $50 \mu \mathrm{l}$ DEPC treated $\mathrm{H}_{2} \mathrm{O}$ (AppliChem) and stored at $-70{ }^{\circ} \mathrm{C}$.

\section{Determination of hIFNY-mRNA and E. coli 16S RNA in purified IBs}

hIFN $\gamma$-mRNA and E. coli 16S RNA were determined by hybridization with $19 \mathrm{nt}$ and $20 \mathrm{nt}$ long ${ }^{32} \mathrm{P}$-labelled oligonucleotides specific for hIFNy gene and E. coli $16 \mathrm{~S}$ rRNA respectively as previously described [54].

\section{Supplementary information}

Supplementary information accompanies this paper at https://doi. org/10.1186/s12934-020-01400-6.

Additional file 1: Fig. S1. UV spectra of nucleic acids isolated from purified IBs by phenol-chloroform extraction and precipitation with ethanol. The probe was analysed by NanoDrop ${ }^{\circledR}$. Fig. S2. UV spectra of RNA isolated from purified IBs by TRIzol ${ }^{\circledR}$ and analysed by NanoDrop ${ }^{\circledR}$.

\section{Abbreviations}

IBs: Inclusion bodies; hIFNy: Human interferon-gamma; PAAG electrophoresis: Polyacrylamide gel electrophoresis; AGEs: Advanced glycation end products; LB: Luria-Bertani (LB) broth; DEPC: Diethylpyrocarbonate.

\section{Authors' contributions}

II and GN designed the experiments. EK performed the experiments. GN and EK analyzed and interpreted the data. EK wrote the manuscript. GN and II revised the manuscript. All authors read and approved the final manuscript.

\section{Funding}

This work was supported by Grant DN-11/20/2017 from Bulgarian Science Fund and by the National Research Program "Young scientists and postdoctoral student" DCM \# 577/2018 from Ministry of Education and Science, Bulgaria.

Availability of data and materials

All data generated or analyzed during this study are included in this article.

Ethics approval and consent to participate Not applicable.

Consent for publication

Not applicable.

Competing interests

The authors declare that they have no competing interests.

Received: 3 May 2020 Accepted: 7 July 2020

Published online: 11 July 2020

References

1. De Marco A, Ferrer-Miralles N, Garcia-Fruitós E, Mitraki A, Peternel S, Rinas U, Trujillo-Roldán MA, Valdez-Cruz NA, Vázquez E, Villaverde A. Bacterial inclusion bodies are industrially exploitable amyloids. FEMS Microbiol Rev. 2019;43(1):53-72. https://doi.org/10.1093/femsre/fuy038.

2. Rinas U, Garcia-Fruitós E, Corchero JL, Vázquez E, Seras-Franzoso J, Villaverde A. Bacterial inclusion bodies: discovering their better half. 
Trends Biochem Sci. 2017;42(9):726-37. https://doi.org/10.1016/j. tibs.2017.01.005.

3. Baneyx F, Mujacic M. Recombinant protein folding and misfolding in Escherichia coli. Nat Biotechnol. 2004;22(11):1399. https://doi.org/10.1038/ nbt1029.

4. Wang W, Nema S, Teagarden D. Protein aggregation — pathways and influencing factors. Int J Pharm. 2010;390(2):89-99. https://doi. org/10.1016/j.jpharm.2010.02.025.

5. Slouka C, Kopp J, Spadiut O, Herwig C. Perspectives of inclusion bodies for bio-based products: curse or blessing? Appl Microbiol Biotechnol. 2019;103(3):1 143-53. https://doi.org/10.1007/s00253-018-9569-1.

6. Gifre-Renom L, Seras-Franzoso J, Rafael D, Andrade F, Cano-Garrido O, Martinez-Trucharte F, Ugarte-Berzal E, Martens E, Boon L, Villaverde A, Opdenakker G. The biological potential hidden in inclusion bodies. Pharmaceutics. 2020;12(2):157. https://doi.org/10.3390/pharmaceutics12 020157.

7. Carratalá JV, Cano-Garrido O, Sánchez J, Membrado C, Pérez E, ConchilloSolé O, Daura X, Sánchez-Chardi A, Villaverde A, Arís A, Garcia-Fruitós E. Aggregation-prone peptides modulate activity of bovine interferon gamma released from naturally occurring protein nanoparticles. New Biotechnol. 2020;25(57):11-9. https://doi.org/10.1016/j.nbt.2020.02.001.

8. Sánchez JM, López-Laguna H, Álamo P, Serna N, Sánchez-Chardi A, Nolan V, Cano-Garrido O, Casanova I, Unzueta U, Vazquez E, Mangues R. Artificial inclusion bodies for clinical development. Adv Sci. 2019. https://doi. org/10.1002/advs.201902420.

9. Slouka C, Kopp J, Hutwimmer S, Strahammer M, Strohmer D, Eitenberger E, Schwaighofer A, Herwig C. Custom made inclusion bodies: impact of classical process parameters and physiological parameters on inclusion body quality attributes. Microb Cell Fact. 2018;17(1):148. https://doi. org/10.1186/s12934-018-0997-5.

10. Gatti-Lafranconi P, Natalello A, Ami D, Doglia SM, Lotti M. Concepts and tools to exploit the potential of bacterial inclusion bodies in protein science and biotechnology. FEBS J. 2011;278(14):2408-18. https://doi.org/10 $.1111 / \mathrm{j} .1742-4658.2011 .08163 . x$.

11. Singhvi P, Saneja A, Srichandan S, Panda AK. Bacterial inclusion bodies: a treasure trove of bioactive proteins. Trends Biotechnol. 2020;38(5):474-86. https://doi.org/10.1016/j.tibtech.2019.12.011.

12. Philo JS, Arakawa T. Mechanisms of protein aggregation. Curr Pharm Biotechnol. 2009;10(4):348-51. https://doi.org/10.2174/138920109788488 932.

13. Morris AM, Watzky MA, Finke RG. Protein aggregation kinetics, mechanism, and curve-fitting: a review of the literature. Biochim Biophys Acta Proteins Proteom. 2009;1794(3):375-97. https://doi.org/10.1016/j.bbapa p.2008.10.016.

14. Weiss WF IV, Young TM, Roberts CJ. Principles, approaches, and challenges for predicting protein aggregation rates and shelf life. J Pharm Sci. 2009;98(4):1246-77. https://doi.org/10.1002/jps.21521.

15. Hamada $\mathrm{H}$, Arakawa T, Shiraki K. Effect of additives on protein aggregation. Curr Pharm Biotechnol. 2009;10(4):400-7. https://doi. org/10.2174/138920109788488941.

16. Andrews JM, Roberts CJ. A Lumry-Eyring nucleated polymerization model of protein aggregation kinetics: 1. Aggregation with pre-equilibrated unfolding. J Phys Chem B. 2007;111(27):7897-913. https://doi. org/10.1021/jp070212j.

17. Buck PM, Kumar S, Wang X, Agrawal NJ, Trout BL, Singh SK. Computational methods to predict therapeutic protein aggregation. In: Voynov $V_{\text {, }}$ Caravella JA, editors. Therapeutic proteins. Totowa: Humana Press; 2012. p. 425-51. https://doi.org/10.1007/978-1-61779-921-1_26.

18. Jürgen B, Breitenstein $A$, Urlacher V, Büttner $K$, Lin H, Hecker M, Schweder T, Neubauer P. Quality control of inclusion bodies in Escherichia coli. Microb Cell Fact. 2010;9(1):41. https://doi.org/10.1186/1475-2859-9-41.

19. Conchillo-Solé O, de Groot NS, Avilés FX, Vendrell J, Daura X, Ventura S. AGGRESCAN: a server for the prediction and evaluation of" hot spots" of aggregation in polypeptides. BMC Bioinform. 2007;8(1):65. https://doi. org/10.1186/1471-2105-8-65.

20. de Groot NS, Pallarés I, Avilés FX, Vendrell J, Ventura S. Prediction of" hot spots" of aggregation in disease-linked polypeptides. BMC Struct Biol. 2005;5(1):18. https://doi.org/10.1186/1472-6807-5-18.

21. Ventura S. Sequence determinants of protein aggregation: tools to increase protein solubility. Microb Cell Fact. 2005;4(1):11. https://doi org/10.1186/1475-2859-4-11.
22. Villaverde A, Carrió MM. Protein aggregation in recombinant bacteria: biological role of inclusion bodies. Biotechnol Lett. 2003;25(17):1385-95. https://doi.org/10.1023/A:1025024104862.

23. Espargaró A, Castillo V, de Groot NS, Ventura S. The in vivo and in vitro aggregation properties of globular proteins correlate with their conformational stability: the SH3 case. J Mol Biol. 2008;378(5):1116-31. https:// doi.org/10.1016/j.jmb.2008.03.020.

24. Rinas U, Bailey JE. Protein compositional analysis of inclusion bodies produced in recombinant Escherichia coli. Appl Microbiol Biotechnol. 1992;37(5):609-14. https://doi.org/10.1007/BF00240735.

25. Rinas U, Boone TC, Bailey JE. Characterization of inclusion bodies in recombinant Escherichia coli producing high levels of porcine somatotropin. J Biotechnol. 1993;28(2-3):313-20. https://doi.org/10.1016/01681656(93)90179-Q.

26. Valax P, Georgiou G. Molecular characterization of beta-lactamase inclusion bodies produced in Escherichia coli. 1. Composition. Biotechnol Prog. 1993;9(5):539-47. https://doi.org/10.1021/bp00023a014.

27. Carrio MM, Corchero JL, Villaverde A. Dynamics of in vivo protein aggregation: building inclusion bodies in recombinant bacteria. FEMS Microbiol Lett. 1998;169(1):9-15. https://doi.org/10.1111/j.1574-6968.1998. tb13292.x.

28. Singh SM, Panda AK. Solubilization and refolding of bacterial inclusion body proteins. J Biosci Bioeng. 2005;99(4):303-10. https://doi. org/10.1263/jbb.99.303.

29. Veinger L, Diamant S, Buchner J, Goloubinoff P. The small heat-shock protein IbpB from Escherichia coli stabilizes stress-denatured proteins for subsequent refolding by a multichaperone network. J Biol Chem. 1998;273(18):11032-7. https://doi.org/10.1074/jbc.273.18.11032.

30. Allen SP, Polazzi JO, Gierse JK, Easton AM. Two novel heat shock genes encoding proteins produced in response to heterologous protein expression in Escherichia coli. J Bacteriol. 1992;174(21):6938-47. https://doi. org/10.1128/jb.174.21.6938-6947.1992.

31. Hoffmann F, Rinas U. Kinetics of heat-shock response and inclusion body formation during temperature-induced production of basic fibroblast growth factor in high-cell-density cultures of recombinant Escherichia coli. Biotechnol Prog. 2000;16(6):1000-7. https://doi.org/10.1021/bp000 0959.

32. Carrio MM, Villaverde A. Construction and deconstruction of bacterial inclusion bodies. J Biotechnol. 2002;96(1):3-12. https://doi.org/10.1016/ S0168-1656(02)00032-9.

33. Jürgen B, Lin HY, Riemschneider S, Scharf C, Neubauer P, Schmid R, Hecker M, Schweder T. Monitoring of genes that respond to overproduction of an insoluble recombinant protein in Escherichia coli glucoselimited fed-batch fermentations. Biotechnol Bioeng. 2000;70(2):217-24. https://doi.org/10.1002/1097-0290(20001020)70:2\%3c217:AID-BIT11 \%3e3.0.CO;2-W.

34. Chaturvedi R, Bhakuni V, Tuli R. The $\delta$-endotoxin proteins accumulate in Escherichia coli as a protein-DNA complex that can be dissociated by hydrophobic interaction chromatography. Protein Expr Purif. 2000;20(1):21-6. https://doi.org/10.1006/prep.2000.1270.

35. Hartley DL, Kane JF. Properties of inclusion bodies from recombinant Escherichia coli. Biochem Soc Trans. 1988;16(2):101-2.

36. Kane JF, Hartley DL. Properties of recombinant protein-containing inclusion bodies in Escherichia coli. Bioprocess Technol. 1991;12:121-45.

37. Hart RA, Rinas U, Bailey JE. Protein composition of Vitreoscilla hemoglobin inclusion bodies produced in Escherichia coli. J Biol Chem. 1990;265(21):12728-33.

38. Wasmer C, Benkemoun L, Sabaté R, Steinmetz MO, Coulary-Salin B, Wang L, Riek R, Saupe SJ, Meier BH. Solid-state NMR spectroscopy reveals that E. coli inclusion bodies of HET-s (218-289) are amyloids. Angew Chem Int Ed. 2009;48(26):4858-60. https://doi.org/10.1002/anie.200806100.

39. Futami J, Fujiyama H, Kinoshita R, Nonomura H, Honjo T, Tada H, Matsushita H, Abe Y, Kakimi K. Denatured mammalian protein mixtures exhibit unusually high solubility in nucleic acid-free pure water. PLOS ONE. 2014;9(11):e113295. https://doi.org/10.1371/journal.pone.0113295.

40. Rodríguez-Carmona E, Cano-Garrido O, Seras-Franzoso J, Villaverde A, García-Fruitós E. Isolation of cell-free bacterial inclusion bodies. Microb Cell Fact. 2010;9(1):71. https://doi.org/10.1186/1475-2859-9-71.

41. Petrov S, Nacheva G, Ivanov I. Purification and refolding of recombinant human interferon-gamma in urea-ammonium chloride solution. Protein Expr Purif. 2010;73(1):70-3. https://doi.org/10.1016/j.pep.2010.03.026. 
42. Chomczynski P, Sacchi N. Single-step method of RNA isolation by acid guanidinium thiocyanate-phenol-chloroform extraction. Anal Biochem. 1987;162(1):156-9. https://doi.org/10.1016/0003-2697(87)90021-2.

43. Neerathilingam M, Mysore S, Gandham SH. Soni-removal of nucleic acids from inclusion bodies. Biochem Biophys Res Commun. 2014;448(1):45-9. https://doi.org/10.1016/j.bbrc.2014.04.049.

44. Futami J, Tsushima Y, Tada H, Seno M, Yamada H. Convenient and efficient in vitro folding of disulfide-containing globular protein from crude bacterial inclusion bodies. J Biochem. 2000;127(3):435-41. https://doi. org/10.1093/oxfordjournals.jbchem.a022625.

45. Baker TA, Kornberg A. Transcriptional activation of initiation of replication from the E. coli chromosomal origin: an RNA-DNA hybrid near oriC. Cell. 1988;55(1):113-23. https://doi.org/10.1016/0092-8674(88)90014-1.

46. Popov M, Petrov S, Kirilov K, Nacheva G, Ivanov I. Segregational instability in E. coli of expression plasmids carrying human interferon gamma gene and its 3 '-end truncated variants. Biotechnol Biotechnol Equip. 2009;23(sup1):840-3. https://doi.org/10.1080/13102818.2009.10818553.

47. Popov M, Petrov S, Nacheva G, Ivanov I, Reichl U. Effects of a recombinant gene expression on ColE1-like plasmid segregation in Escherichia coli. BMC Biotechnol. 2011;11(1):18. https://doi.org/10.1186/1472-6750-11-18.

48. Mironova R, Niwa T, Hayashi H, Dimitrova R, Ivanov I. Evidence for non-enzymatic glycosylation in Escherichia coli. Mol Microbiol. 2001;39(4):1061-8. https://doi.org/10.1046/j.1365-2958.2001.02304.x.

49. Mironova R, Niwa T, Handzhiyski Y, Sredovska A, Ivanov I. Evidence for non-enzymatic glycosylation of Escherichia coli chromosomal
DNA. Mol Microbiol. 2005;55(6):1801-11. https://doi.org/10.111 1/j.1365-2958.2005.04504.x

50. Mironova R, Niwa T, Dimitrova R, Boyanova M, Ivanov I. Glycation and post-translational processing of human interferon-gamma expressed in Escherichia coli. J Biol Chem. 2003;278(51):51068-74. https://doi. org/10.1074/jbc.m307470200.

51. Boteva E, Mironova R. Maillard reaction and aging: can bacteria shed light on the link? Biotechnol Biotechnol Equip. 2019;33(1):481-97. https://doi. org/10.1080/13102818.2019.1590160

52. Sambrook J, Russell DW. Purification of nucleic acids by extraction with phenol: chloroform. Cold Spring Harbor Protoc. 2006;2006(1):pdbrot4455. https://doi.org/10.1101/pdb.prot4455.

53. Green MR, Sambrook J. Precipitation of DNA with ethanol. Cold Spring Harb Protoc. 2016. https://doi.org/10.1101/pdb.prot093377.

54. Nacheva G, Todorova K, Boyanova M, Berzal-Herranz A, Karshikoff A, Ivanov I. Human interferon gamma: significance of the C-terminal flexible domain for its biological activity. Arch Biochem Biophys. 2003;413(1):918. https://doi.org/10.1016/S0003-9861(03)00113-9.

\section{Publisher's Note}

Springer Nature remains neutral with regard to jurisdictional claims in published maps and institutional affiliations.
Ready to submit your research? Choose BMC and benefit from:

- fast, convenient online submission

- thorough peer review by experienced researchers in your field

- rapid publication on acceptance

- support for research data, including large and complex data types

- gold Open Access which fosters wider collaboration and increased citations

- maximum visibility for your research: over $100 \mathrm{M}$ website views per year

At BMC, research is always in progress.

Learn more biomedcentral.com/submissions 